\title{
Diversifying Effect of Digital Competence
}

\author{
Adrián Csordás
}

Department of Business Informatics, Faculty of Economics and Business, University of Debrecen, Hungary

\begin{abstract}
Information and communication technology determines not only the development of companies but also the development of nations. Among other things, with the usage of eGovernment, the administrations can put „digitally pressure“ on their citizens which can lead to the appreciation of the role of digital competence. Based on data from the European Statistical Office, the digital competences of the EU Member States were examined between 2015 and 2017. A significant relationship was found between the level of digital knowledge and the level of unemployment. There is a strong positive correlation between the levels of digital competence and corporates training. In the clustering of countries, three distinct groups were created. The underdeveloped, developing and developed countries differed not only in the number of digitally educated people but also in the distribution of the digitally qualified groups.
\end{abstract}

JEL Classification: D83, E24, M53

\section{Keywords}

ICT, EU, unemployment, training.

Csordás, A. (2020) "Diversifying Effect of Digital Competence", AGRIS on-line Papers in Economics and Informatics, Vol. 12, No. 1, pp. 3-13. ISSN 1804-1930. DOI 10.7160/aol.2020.120101.

\section{Introduction}

In our decade the main challenges for companies are neither technological trends, disruptive innovations, nor new customer behaviors. Their aim is to adapt their throughway, culture, and competencies to the new, digital way of working (Accenture, 2016; Maedche, 2016). What kind of change does this revolution cause for the workforce (Murawski and Bick, 2017)? The publication of Frey and Osborne generated the biggest attention (Frey and Osborne, 2013). They estimated that $47 \%$ of current US employment is at risk due to computerization. Among other things, as a result of this alarming article, several new reports on this topic have been published recently (Autor, 2015; Miroudot et al., 2016). The numerical results and conclusions of these reports are not similar, but they agree that the concept of work is going to change significantly in the coming decades (Murawski and Bick, 2017). The macroeconomic scientists are still focusing on the numerical results and conclusions of their reports, while the consequences for the individual workers are often neglected (Wang and Haggerty, 2011). One of the most important questions is "Which digital competencies are required for employability in the digital age (Dubey and Gunasekaran, 2015)"?

But what does digital competence exactly mean?

The concept of digital competence has not yet been applied consistently (Vieru, 2015). There are several ways to define it (Ferrari, 2012) because the existing definitions are quite general (Hoel and Holtkamp, 2012). Digital competence is one of the eight key competencies that are essential for lifelong learning within the European Union. Anusca Ferrari determines it as the confident, critical and creative use of Information and Communications Technology to achieve goals related to work, employability, learning, leisure, inclusion and/or participation in society. It is also a transversal key competence (Ferrari, 2013). It means with the help of digital competence possible to acquire other key competencies (e.g. language, mathematics, learning to learn, cultural awareness).

We can see the rapid change in computer software and hardware, which can make learned skills redundant (Lengyel et al., 2017). However, there are fundamental and enduring concepts of digital competencies that will be important for future 
job seekers to master them (Hajkowicz et al., 2016). Educational institutions, governments and the players of the industry need to work together to develop the right e-skills, which increase competitiveness and productivity (Herdon et al., 2015). Because of ICT, people have a large digital footprint so the e-business and internet marketing are now easily mass-customized. Fake news is also often found on social sites, so it is important to learn the basics of digital literacy at a young age, including which source or database we consider reliable. The introduction of the blockchain could help to replace a trusted third-party in the verification and authentication of information. Although researchers have great hopes for blockchain-based technologies, while they are sufficiently transformative and fundamental, it is really difficult to evaluate its payback. Since 2010, Israeli schools have been gradually implementing the National ICT Program to align the education system to the digital era (Albion et al., 2015). Of course, the skills, beliefs, and attitudes of the teachers affect the effectiveness of ICT integration (Blau and Peled, 2012). They need to perceive the integration of technology in education as an integral part of the development of professional knowledge in order to maximize the potential impact of technology on teaching and learning (Wang et al., 2014). This could among other things, reduce the digital gap that causes more and more difficulties for university teachers and companies (Várallyai et al., 2015). The increased usage of digital technologies at work raises the demand for new skills. The employees need to acquire generic ICT skills to be able to use new technologies in their daily work (Australian Industry Group, 2018). However, technology has blurred borders between work and non-work activities (Reyt and Wiesenfeld, 2015). The use of the Internet, e-mailing and the use of social media is also an integral part of the work, but they can also be easily used to communicate with family and friends (Colbert et al., 2016). In spite of this according to Beitz ICT skills and capabilities are important for the whole workforce and not just those engaged in specialist ICT roles (Beitz, 2015).

Mohammadyari and Singh have shown that the digital competence of the workforce can contribute to successful technology adoption outcomes (Mohammadyari and Singh, 2015).

It is also important, that the companies need to invest not only in the technologies but also in people and skills. That is how they can enable the workforce uses the technologies optimally. With these acts the companies can reach, what Soule et al. called ,digital dexterity” (Soule et al., 2016).

\section{Materials and methods}

To analyze the context of digital competence and human resources, a comprehensive dataset was needed which consisting of variables measuring ICT competences and some macroeconomics indicators of several countries globally. National statistical offices often estimate domestic values in their own national currencies. That is why they are not directly international comparable. The data was compiled after reviewing the databases of several international organizations. The main sources of the database were the European Statistical Office (Eurostat) and the OECD. Due to the limited accessibility of ICTs data for developing countries, only 28 members of the European Union were analyzed, during the period of 2015 - 2017. Cyprus and Malta did not have enough data in the database of Eurostat to be part of the research. The quantity of these data and the period under review are not as big as, they would be ideal, but it can be enough to illustrate proportions and directions. The variables which were used in this research are shown in Table 1.

The vast majority of terms in the table are clear, but there are some definitions that need to be clarified.

When the Eurostat classified the individuals, according to their digital skills, it had to compose digital skills indicators which are based on selected activities related to internet or software use performed by individuals aged 16-74 in four specific areas (information, communication, problem-solving, software skills). The participants completed a self-assessment survey. In most Member States the final sample size was between 3000 and 6000 elements.

When we summarize these results from the four fields, we can divide the next four groups:

- no skills: Digitally illiterate. He could not solve any tasks, despite he used the internet at least once during the last 3 months.

- low: He could not pass minimum one, maximum three tasks from the four areas.

- basic: He could solve all of the tasks, and he passed at least one at the "basic" level.

- above basic: He passed all of the tasks at the "above basic" level (Eurostat, 2019).

The database was analyzed with SPSS software. In the first step, the relationships were examined between the variables. The direction and strength of the relationship between them are determined by Pearson's correlation coefficient. During the correlation analysis, the value range is between 1 and -1 . If the absolute value of the coefficient 


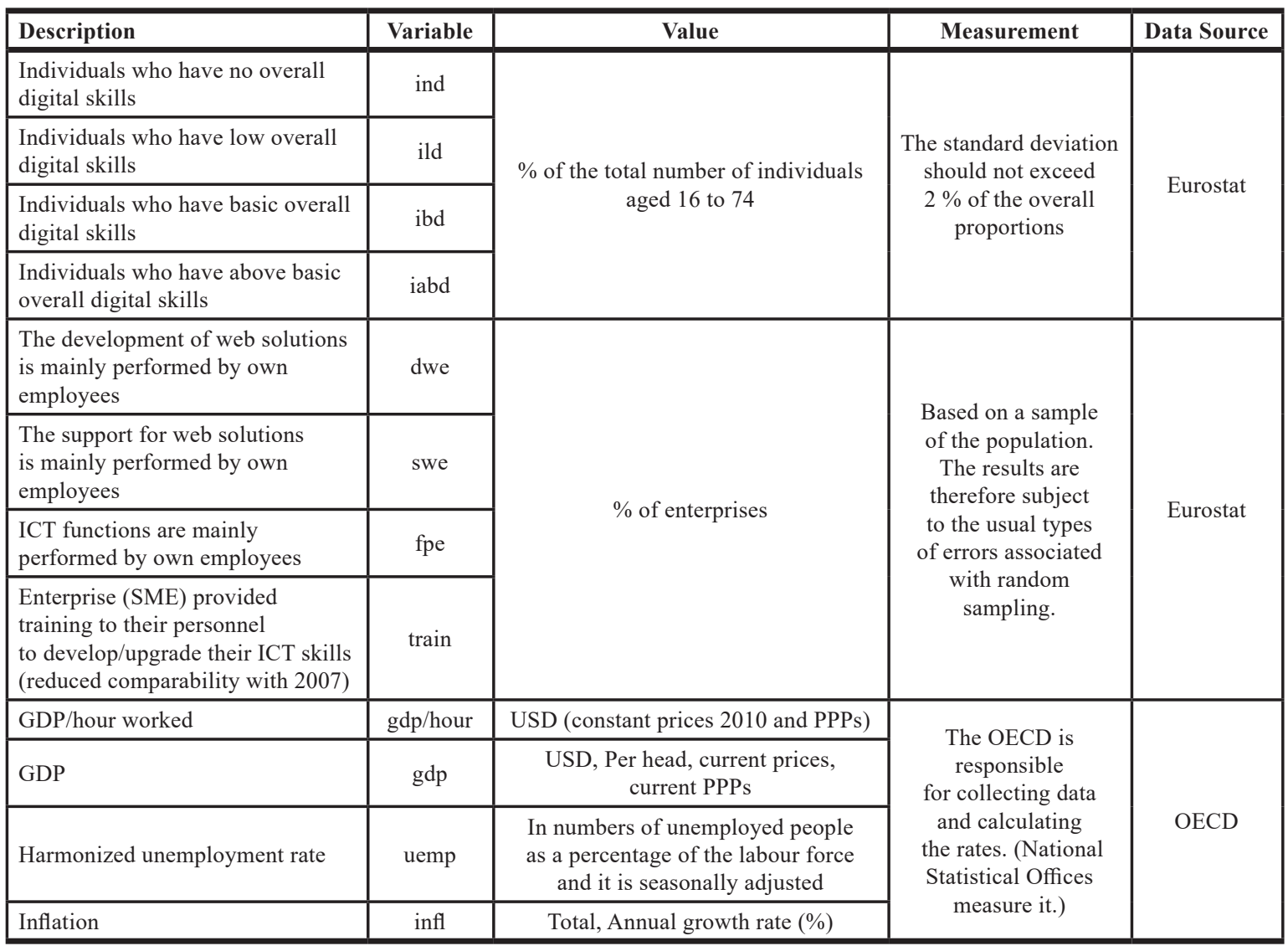

Source: own elaboration

Table 1: Descriptive of variables used in models.

is close to one, it means that there is a strong relationship between the two studied variables (co-movement). If the value is positive, they move in the same direction (together), while in the case of a negative value, they move in the opposite direction (Field, 2013).

The classification of the countries of the European Union according to their level of development was made by K-Mean Method. The classification of similar things is called clustering, where the alike items are placed into groups. The basic purpose of this is to classify the observed units into relatively homogeneous groups, which are based on certain aspects. Among the hierarchical clustering methods, the use of Ward and the average chain method are quite popular, but they increasingly become "complementary" to non-hierarchical methods. The best solution is to run a hierarchical method first, to find out how much the ideal number of clusters would be, and then to run the non-hierarchical method, where we set that value to the number of groups. In our case, the singular use of the K-Mean Method was sufficient, because our goal was to define a predetermined number of groups (underdeveloped, developing and developed) (Sajtos and Mitev, 2007). The K-Means clustering algorithm uses $k$ as a parameter, divide $n$ objects into $k$ clusters. The objects from the same cluster are similar to each other however differing from the other objects which belong to the other clusters. The algorithm tries to find the centers of the clusters, $\left(\mathrm{C}_{1}, \mathrm{C}_{2}, \mathrm{C}_{3}, \ldots \ldots \mathrm{C}_{\mathrm{k}}\right)$, such that the sum of the squared distances of each data point, $x_{i}, 1 \leq i \leq n$, to its nearest cluster center $C_{j}, 1 \leq j \leq k$, is minimized (Arpit et al., 2017).

\section{Results and discussion}

The connection between the analyzed variables

In these countries where the percentage of individuals with basic digital skills is higher, there the harmonized unemployment rate is lower $(-0.273)$, than in those states where the individuals have above-average digital skills (-0.242). It can see in Figure 1. Although the correlation coefficients are quite weak in both cases and the significant level is only $95 \%$, it is obvious that in those places where the citizens do not have a general digital 


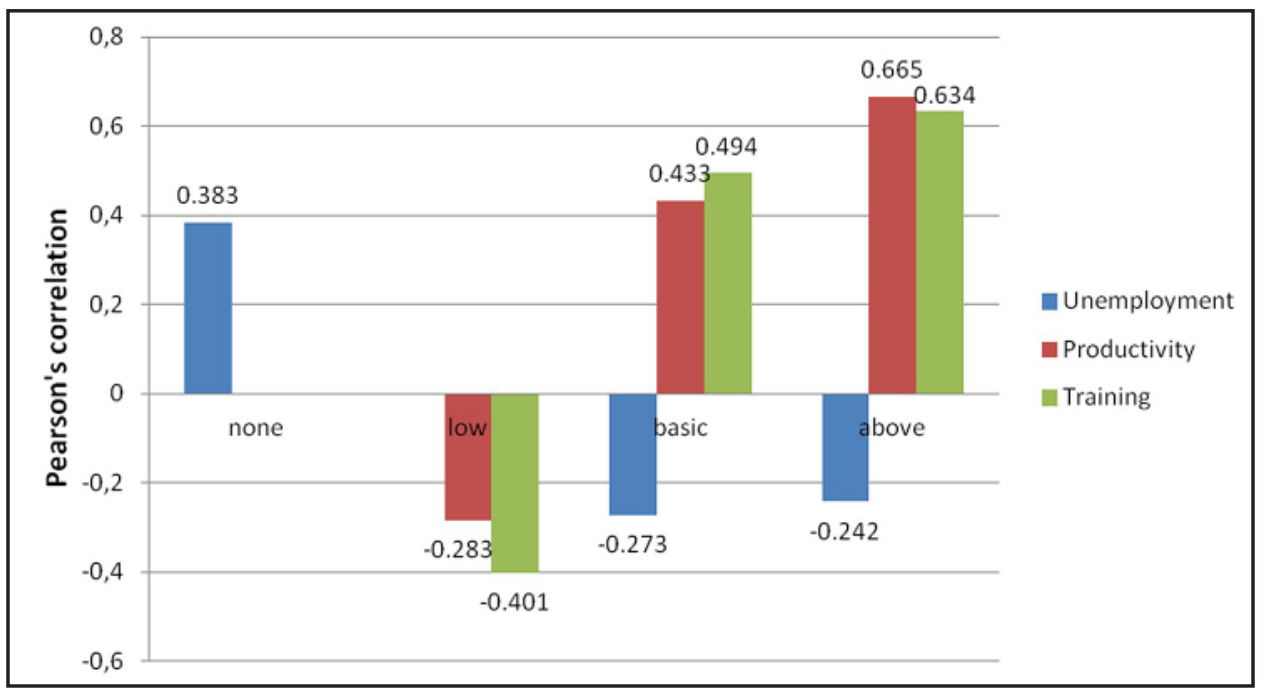

Source: own elaboration

Figure 1: The relationship of different levels of digital competences to unemployment, productivity, and training.

knowledge, the unemployment rate $(0.383$, at $95 \%$ significance level) is higher.

The result is not surprising. Today, even the simplest tasks require some degree of digital knowledge. Because of this, the employment of digital illiterates is difficult.

Kashan and Fouzia had the same result. To own digital skills like usage of computers, the internet and the ability to use other technology are very crucial for getting a job. There are also many other factors like higher education and health, which also affect employability, but these are rather expected in the case of well-payed jobs (Kashan and Fouzia, 2013). According to Bello et al. (2013), ICT skills are one of the most important requirements for employment. In addition, the dynamic nature of the labour market and the demand for new skills are the other considerable factors identified by 21-century studies.

In the Figure 1, the correlation was checked between the rate of productivity and the different level of digital competences too. Apart from digital illiterates, there are significant results for all three groups. In the case of individuals with low digital competence at $95 \%$, in the case of basic and above basic individuals at $99 \%$ significance level, we can say that the higher digital competence means higher productivity.

This may be explained by the fact that higher-skilled people produce higher value-added products. Thus, they generate many more benefits at the same time, or in less time they produce the same benefits. Miikka et al. also think ICT is a potential source of productivity improvement. With the usage of ICT, we can eliminate non-value-adding tasks or make them more efficient. It gives (more) time for the more important tasks. In their study, the usage of ICT saved 19.5 minutes for one person in a week (Miikka et al., 2013). According to Cardona et al. ICT plays an important role in everyday lives, and in productivity as well. The authors say, the effect of the productivity is not only significant and positive but also increasing over time (Cardona et al., 2013), so the usage of ICT will be even more important.

This raises the question, whether companies want to train their less skilled people to produce higher value-added products, or do they promote the already higher qualified people, to further develop their high value-added productivity.

Based on the Figure 1., we can say that companies provide further training to people with at least basic digital competence. In the case of digitally unqualified people, we did not get any significant value, while the other correlation coefficients depicted were measured at $99 \%$ significance level.

It is assumed that the training of unskilled people requires a lot of time and money. It seems economy to further develop the more skilled people. It is logical, that from the "basic" level to ,above" level can be achieved by using fewer resources. The "low" rated people (and the digitally unskilled) would require much more effort to reach the "basic" level.

We can interpret the publication of Khawaja and Nadeem in the same way. According to the authors, there are organizations that develop 
employees who apply their abilities and skills for their organizations and with the training improve their loyalty (Khawaja and Nadeem, 2013). We can assume from the word "develop" that the above mentioned employees have at least a basic qualification. In the case of unskilled labor, they would use the word "train", to teach them the essential of the job.

The work of Costen and Salazar takes the opposite view. According to the results of their survey, which made in the lodging industry, managers need to ensure that all employees receive formal training to help them learn the essential components of their jobs and the company standards associated with successfully performing their jobs (Costen and Salazar 2011). It is important to emphasize that the survey was conducted in the lodging industry, where digital competence and digitization are not so critical, and it is also important to note that unskilled employment is also a feature of this field, which makes it "obligatory" to train the employee.

\section{Classification of countries}

In this research, digital competence is in focus, so for group creation, variables were defined for SPSS such as individuals who have low/basic/above basic digital skills. (It would be more interesting the classification if I would test the different levels of digital skills together with productivity or GDP of the countries. Unfortunately, there was data e.g. Luxembourg's productivity / GDP, which would distort the sample and the further investigation of this would be meaningless.) Using the K-Mean Cluster method, three clusters were generated in the year 2015 . The final cluster centers are shown in Figure 2.

The chart above shows that there are fewer citizens with digital competences in the underdeveloped group than in the developing or in the developed countries. Only $80 \%$ of people have any kind of digital competences in the developing group, however, in the developed group this percentage is higher (94\%).

It is interesting how the dimensions of the groups in the developed countries look like. While in the underdeveloped group we cannot speak of graduality, the developing group already shows that the goal is to expand higher-level groups. This "developing" process is already appearing in a relatively proportional way in developed countries. People with low competencies make up the smallest group (17\%). Almost two times bigger is the group of basic users $(30 \%)$, than the lower cluster. The group of "above" users is the widest. Nearly one and a half times bigger (47\%) than the basic cluster. The most significant difference is in the size of the "Individuals who have the above basic overall digital skills" group.

The Figure 3 shows the classification of countries according to the examined indicators.

Surprisingly only Luxembourg and the Netherlands belong to the group of developed countries from the (EU) founding states. Finland's top ranking is probably due to the excellent education system, which is known for its openness and continuous innovation worldwide (Williams et al., 2013).

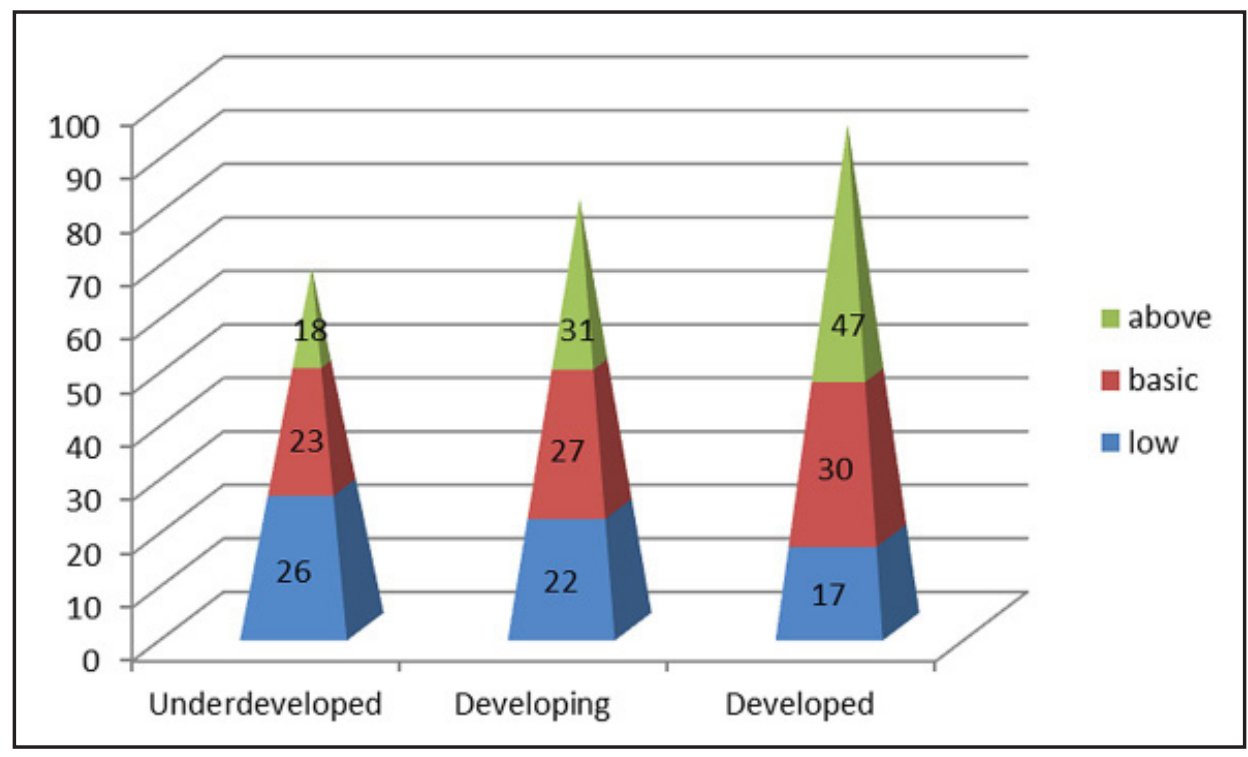

Source: own elaboration

Figure 2: Underdeveloped, developing and developed clusters in 2015. 


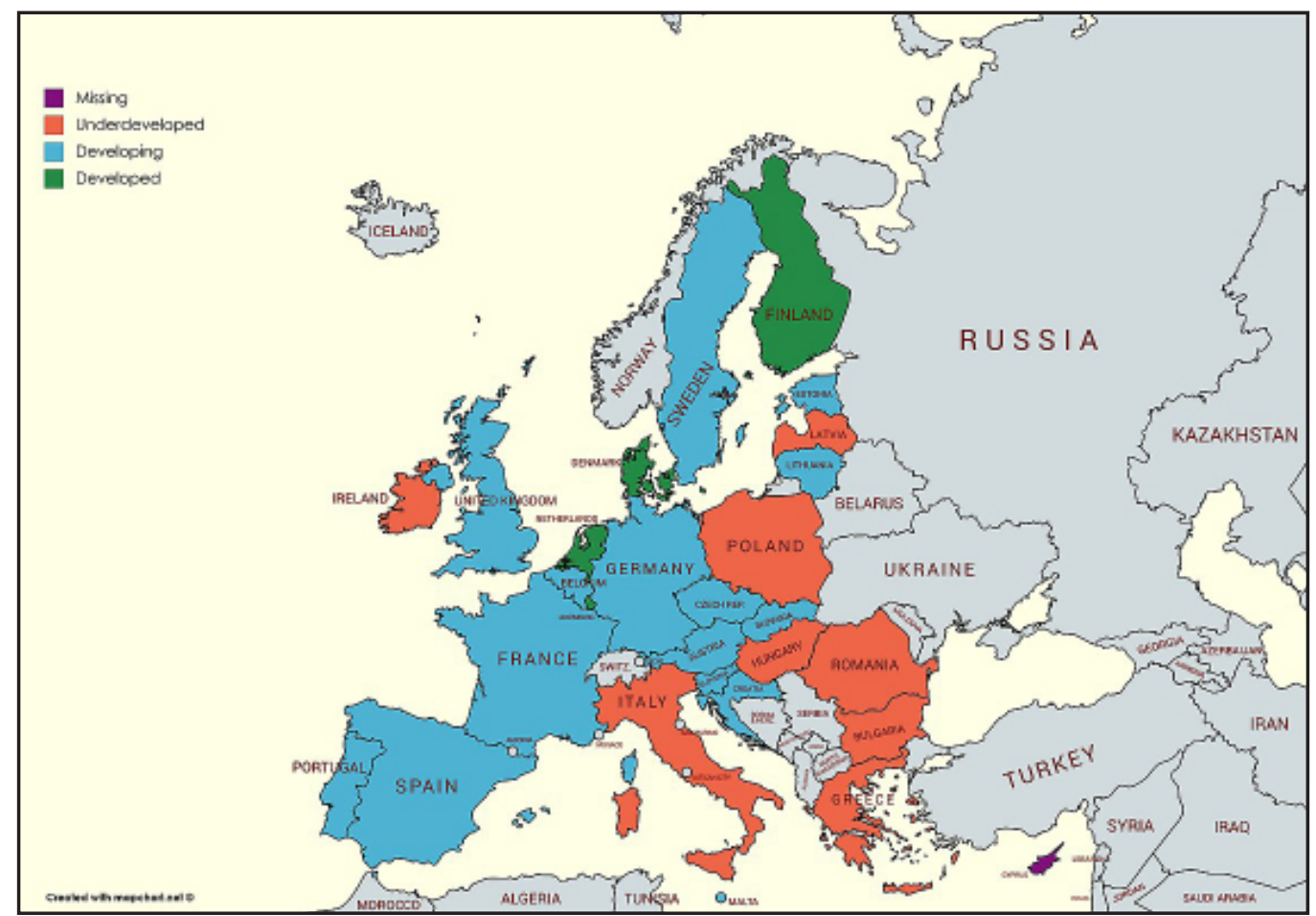

Note: Missing: Cyprus, because it has not enough data to the classification Source: own elaboration

Figure 3: The classification of EU members in the year of 2015.

Denmark's developed classification is also could be connected with its education system and the high standard of living, that even the wealthy Germans are threatened by "brain drain" in Denmark. Excluding Italy, - it is the only founding member who belongs to the group of underdeveloped countries - the other founding member countries are members of the developing group. The otherwise internationally dominant Italy (it is a member of the G7), perhaps offers the locals a faster and easier way to earn money with tourism, thus Italy has individuals with fewer and lower levels of ICT than other founding Member States. Interestingly, Estonia which belongs to the developed Baltic States's, and its administration is almost completely digitalized, in spite of this, this country is not enough developed to be part of the smartest's cluster. Several countries of the underdeveloped group (Hungary, Poland, Romania) are affected by the emigration. In these countries, the unskilled people -who did not move abroad- work in factories that hardly create added value (Figure 4).

In accordance with previous correlation studies, we can see from these pyramids that basic users were trained to the above basic level in the underdeveloped and developed countries (the proportion of basic users decreased as much as, the proportion of users with the above basic level increased), while individuals with low digital competencies were not promoted to reach the "basic" level. (The proportion of users with low digital competence increased, while the proportion of users with basic digital competence decreased) (Figure 5).

When we compare the data of 2015 and 2017, it is clear that the group of developing countries was the largest in both years. During the period under review, Greece and Hungary moved forward from the cluster of underdeveloped countries to the group of developing countries, while Croatia fell to the underdeveloped countries from the developing cluster. The setback of Croatia explicable with its new EU membership. In the first phase after accession (2013.07.01-2015.06.30), 13 EU member states restricted the employment of Croatian citizens, in the second stage (2015.07.01-2018.06.30) only 5 countries applied restrictions against them. From 1 July 2018, only Austria regulates the employment of Croatian citizens (European Commission). Against this background, we can assume that the more skilled workforce emigrated from the country, which led to a decrease in the proportion of digitally competent residents. Sweden and the United Kingdom stepped forward. They moved from developing countries into clusters of developed countries. 


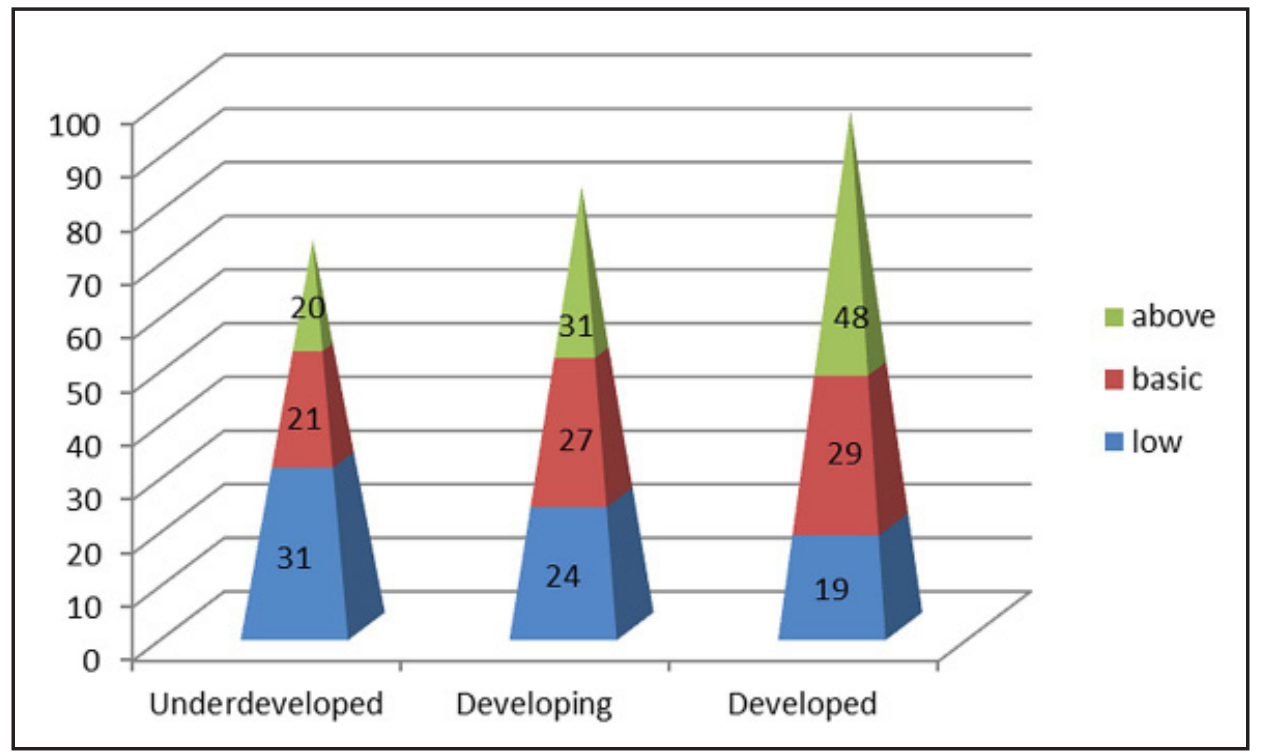

Source: own elaboration

Figure 4: Underdeveloped, developing and developed clusters in the year of 2017.

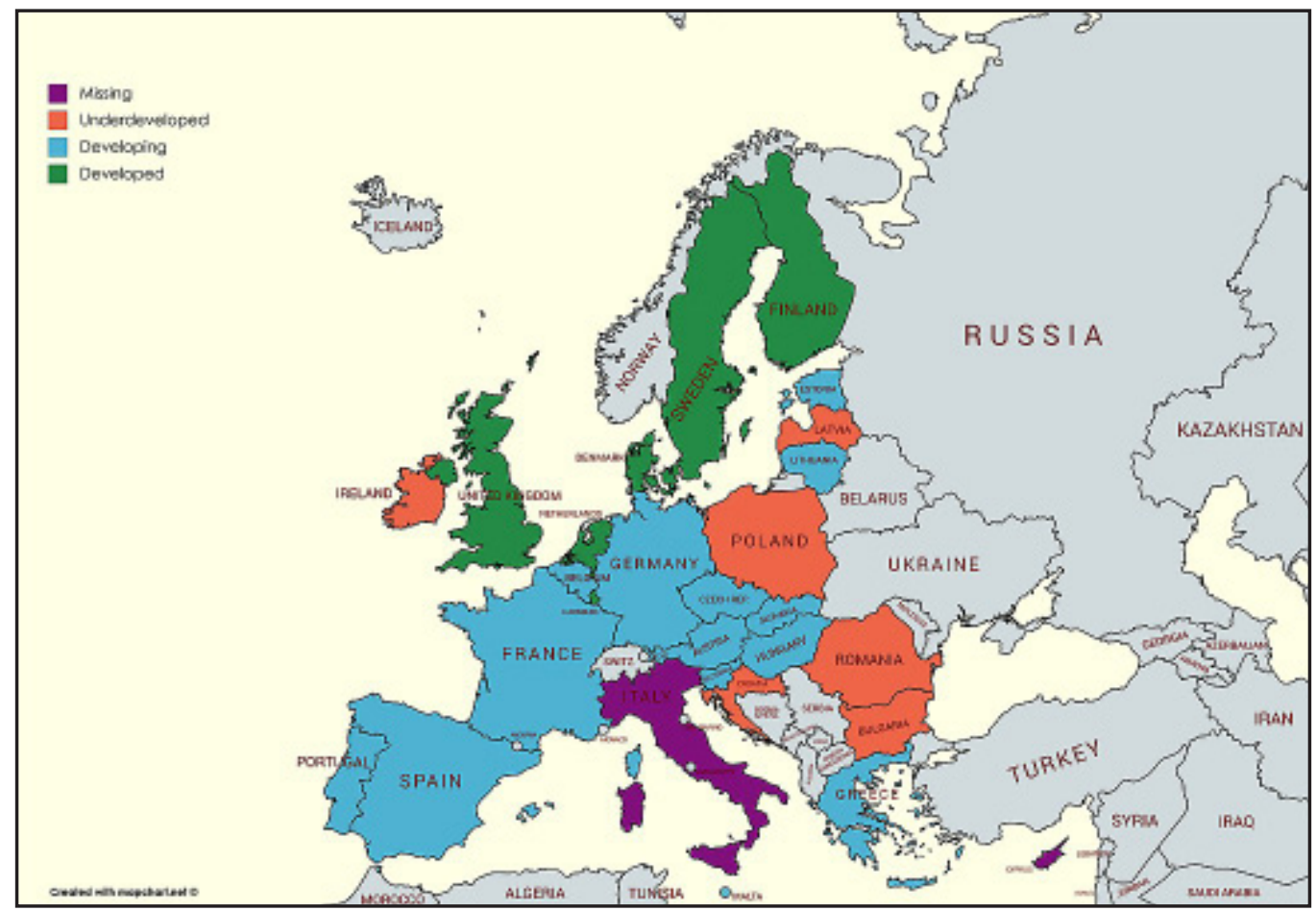

Note: Missing: Cyprus, because it has not enough data to the classification Source: own elaboration

Figure 5: The classification of EU members in the year of 2017.

\section{Conclusion}

A correlation was found between the level of digital competence of the country's residents and the harmonized unemployment rate. In these countries where the citizens own basic digital competence, there the harmonized unemployment rate is lower, than in those countries where individuals have above-basic digital competence. In the lower-skilled countries (where citizens do not have any digital competence), the unemployment rate is higher. Other authors (Kashan and Fouzia, 2013; Bello et al., 2013) also discuss a similar relationship between employability and digital knowledge. 
According to the result of this paper higher digital competence means higher productivity. Higherskilled people generate many more benefits at the same time, or in less time they produce the same benefits. Miikka et al. also think ICT is a potential source of productivity improvement (Miikka et al., 2013). According to Cardona the effect of productivity increasing over time (Cardona et al., 2013). That is while important to keep in mind that e-business and internet marketing are key factors in the 21 st century, which could further boost the economy by engaging less digitally skilled people. In agriculture, the technology (especially GPS, RFDI, IoT) is becoming an increasingly important factor. With blockchain-based systems, this field can bring a new kind of added value (food tracking) that can further expand the economy as a whole, but in the case of large-scale production and cultivation, it also can make the digital competence useless because of automatization.

The openness of companies for training is also influenced by the digital competence of the inhabitants of that country. In these countries where more skilled people live, companies offer more opportunities for further training, than in countries with less educated people. A moderately strong negative correlation was found between low digital competence and workplace training. That means the companies do not offer training in these countries, where low digital educated people live. According to the above statement, an EU country has to create its digitally "educated" competent inhabitants, in order for a company - to reduce the burden of the country and increase its revenues - to further educate the local population. Taking advantage of the "training wave", in the long run, a wide "above" layer can be created with fewer "average" and or "low" digital competences. This can cause (beyond the "reverse competency pyramid" and developed status) the so-called "digital dexterity" by Soule et al (Soule et al., 2016). However not only certain companies can reach it, but also whole sectors.

When the Member States of the European Union were grouped, two interesting findings were made. The biggest difference between the three groups (underdeveloped, developing and developed) was not only the proportion of people with above basic digital competence but also in the proportion of individuals with any digital competence. In addition, in the group of developed countries, we also can observe an interesting phenomenon, the so-called "reverse competence pyramid". This means that as the level of competence increases, the number of individuals who own it increases as well. This reverse pyramid is not observed in underdeveloped countries, while in the developing countries there are signs of ,gradualness". The existence of a "reverse competency pyramid" would also be worth examining in economic areas, where the salaries of high value-added jobs (ICT specialists) do not differ significantly between the countries of the region. Because of the sense of free labor flow within the European Union, a "top" digitally competent programmer can move abroad (by "brain drain") for higher salaries, so instead of they would increase the income and the number of well-educated people in their country of origin, they do these in another country, what we cannot track.

\author{
Corresponding authors \\ Adrián Csordás \\ Department of Business Informatics, Faculty of Economics and Business University of Debrecen \\ Debrecen, Böszörményi út 138 4032, Hungary \\ E-mail: csordas.adrian19@gmail.com
}

\title{
References
}

[1] Accenture (2016) "People First: The Primacy of People in a Digital Age", Accenture Technology Vision 2016. [Online]. Available: https://www.accenture.com/t20160314t114937_w_/us-en/_ acnmedia/accenture/omobono/technologyvision/pdf/technology-trends-technology-vision-2016.pdf [Accessed: 15 May 2019].

[2] Albion, P. R., Tondeur, J., Forkosh-Baruch A. and Peeraer J. (2015) "Teachers' professional development for ICT integration: towards a reciprocal relationship between research and practice", Education and Information Technologies, Vol. 20, No. 4, pp. 655-673. E-ISSN 1573-7608, ISSN 1360-2357. 
[3] Arpit, B., Mayur, S. and Shalini, G. (2017) "Improved K-mean Clustering Algorithm for Prediction Analysis using Classification Technique in Data Mining", International Journal of Computer Applications, Vol. 157, No. 6. ISSN 0975 - 8887. DOI 10.5120/ijca2017912719.

[4] Australian Industry Group (2018) "Developing the Workforce for a Digital Future". [Online]. Available: https://cdn.aigroup.com.au/Reports/2018/Developing_the_workforce_for_a_digital_ future.pdf. [Accessed: 29 Aug. 2019].

[5] Autor, D. H. (2015) "Why are there still so many jobs? The history and future of workplace automation", Journal of Economic Perspectives, Vol. 29 No. 3, pp. 3-30. ISSN 08953309. DOI 10.1257/jep.29.3.3.

[6] Beitz, S. (2015) "Developing the capacity to adapt to industry transformation", in "Australia's future workforce?", Committee for Economic Development of Australia, pp. 156-166. ISBN 0858013002.

[7] Bello, H., Shu'aibu, B., Sukri bin Saud, M. and Buntat, Y. (2013) "ICT Skills for Technical and Vocational Education Graduates' Employability", World Applied Sciences Journal, Vol. 23, No. 2, pp. 204-207. ISSN 1818-4952.

[8] Blau, I. and Peled, Y. (2012) "Teachers' openness to change and attitudes towards ICT: Comparison of Laptop per Teacher and Laptop per Student programs", Interdisciplinary Journal of E-Learning and Learning Objects, Vol. 8, pp. 73-82. E-ISSN 2375-2092, ISSN 2375-2084. DOI 10.28945/1728.

[9] Cardona, M., Kretschmer, T. and Strobel, T. (2013) "ICT and productivity: conclusions from the empirical literature", Information Economics and Policy, Vol. 25, No. 3, pp. 109-125. ISSN 0167-6245. DOI 10.1016/j.infoecopol.2012.12.002.

[10] Colbert, A., Yee, N. and George, G. (2016) "The digital workforce and the workplace of the future". Academy of Management Journal, Vol. 59, No. 3, pp. 731-739. E-ISSN 1948-0989, ISSN 0001-4273. DOI 10.5465/amj.2016.4003.

[11] Costen, W. M. and Salazar, J. (2011) "The Impact of Training and Development on Employee Job Satisfaction, Loyalty, and Intent to Stay in the Lodging Industry", Journal of Human Resources in Hospitality \& Tourism, Vol. 10, No. 3, pp. 273-284. E-ISSN 1533-2853, ISSN 1533-2845. DOI 10.1080/15332845.2011.555734.

[12] Dubey, R. and Gunasekaran, A. (2015) "Education and training for successful career in big data and business analytics", Industrial and Commercial Training, Vol. 47 No. 4, pp. 174-181. ISSN 0019-7858. DOI 10.1108/ICT-08-2014-0059.

[13] EUROPEAN COMMISSION (2018) "Horvátország - Foglalkoztatás, szociális ügyek és társadalmi befogadás - Európai Bizottság". [Online]. Available: https://ec.europa.eu/social/main. jsp?catId=1067\&langId=hu. [Accessed: 30 Jun. 2019].

[14] Eurostat, (2019) „Individuals who have basic or above basic overall digital skills by sex". [Online]. Available: https://ec.europa.eu/eurostat/cache/metadata/en/tepsr_sp410_esmsip2.htm. [Accessed: 17 Sept.2019].

[15] Ferrari, A. (2012) "Digital Competence in Practice: An Analysis of Frameworks", European Commission, Joint Research Center, Institute for Prospective Technological Studies. [Online]. Available: $\quad$ https://ec.europa.eu/digital-single-market/en/news/digital-competence-practiceanalysis-frameworks. [Accessed: 10 June 2019].

[16] Ferrari, A. (2013) “DIGCOMP: A Framework for Developing and Understanding Digital Competence in Europe". [Online]. Available: https://publications.europa.eu/en/publication-detail/-/publication/ a410aad4-10bf-4d25-8c5a-8646fe4101f1/language-en [Accessed: 10 June 2019].

[17] Field, A. (2013) "Discovering statistics using IBM SPSS Statistics" paperback (4 ${ }^{\text {th }}$ ed.). Thousand Oaks, CA, USA: SAGE Publications. ISBN-13: 978-9351500827, ISBN-10: 1446249182.

[18] Frey, C. B. and Osborne, M. A. (2013) "The Future of Employment: How Susceptible are Jobs to Computerization?", Oxford University Programme on the Impacts of Future Technology, 72. p. 
[19] Hajkowicz, S., Reeson A., Rudd, L., Bratanova, A., Hodgers, L., Mason, C. and Boughen, N. (2016) "Tomorrow's Digitally Enabled Workforce", Commonwealth Scientific and Industrial Research Organisation, [Online]. Available: https://data61.csiro.au/en/Our-Work/Future-Cities/Planningsustainable-infrastructure/Tomorrows-Digitally-Enabled-Workforce [Accessed: 17 Sept.2019].

[20] Herdon, M., Botos, S. and Várallyai, L. (2015) "Decreasing the Digital Divide by Increasing E-Innovation and E-Readiness Abilities in Agriculture and Rural Areas", International Journal of Agricultural and Environmental Information Systems, Vol. 6, No. 1, pp. 1-18. E-ISSN 1947-3206, ISSN 1947-3192. DOI 10.4018/ijaeis.2015010101.

[21] Hoel, T. and Holtkamp, P. (2012) "Requirements modelling in international information systems design - what competencies are needed and how to manage them?", ECKM '12: Proceedings of the $13^{\text {th }}$ European Conference on Knowledge Management, Cartagena, Spain, pp. 466-475.

[22] Kashan, P. and Fouzia, N. K. (2013) "Measuring Relationship between Digital Skills and Employability", European Journal of Business and Management, Vol. 5, No. 24. E-ISSN 2222-2839, ISSN 2222-1905.

[23] Khawaja, J. and Nadeem, A. B. (2013) "Training and Development Program and its Benefits to Employee and Organization: A Conceptual Study", European Journal of Business and Management, Vol. 5, No. 2, 2013, E-ISSN 2222-2839, ISSN 2222-1905.

[24] Lengyel, P., Herdon, M., Pancsira, J., Ráthonyi, G. and Füzesi, I. (2017) "The E-learning system success assessment of the service quality using binominal logistic regression", Journal on Efficiency and Responsibility in Education and Science, Vol. 10, No. 2, pp. 51-57. E-ISSN 1803-1617, ISSN 2336-2375. DOI 10.7160/eriesj.2017.100203.

[25] Maedche, A. (2016) "Interview with Michael Nilles on "What makes leaders successful in the age of the digital transformation?", Business \& Information Systems Engineering, Vol. 58, No. 4, pp. 287-289. E-ISSN 1867-0202, ISSN 2367-7005.

[26] Miikka P., Antti, L. and Maiju, V. (2013) "Analysing the impacts of ICT on knowledge work productivity", Journal of Knowledge Management, Vol. 17, No. 4, pp. 545-557. ISSN 1367-3270. DOI 10.1108/JKM-03-2013-0113.

[27] Miroudot, S., Marcolin, L. and Squicciarini, M. (2016) "Routine Jobs, Employment and Technological Innovation in Global Value Chains", OECD Science, Technology and Industry Working Papers. DOI 10.1787/5jm5dcz2d26j-en.

[28] Mohammadyari, S. and Singh, H. (2015) "Understanding the Effect of e-Learning on Individual Performance: The Role of Digital Literacy", Computers \& Education, Vol. 82, pp. 11-25. ISSN 0360-1315. DOI 10.1016/j.compedu.2014.10.025.

[29] Murawski, M. and Bick, M. (2017) "Digital competences of the workforce - a research topic?” Business Process Management Journal, Vol. 23, No. 3, pp. 721-734. ISSN 1463-7154. DOI 10.1108/BPMJ-06-2016-0126.

[30] Reyt, J. and Wiesenfeld, B. M. (2015) "Seeing the forest for the trees: Exploratorylearning, mobile technology, and knowledge workers' role integration behaviors", Academy of Management Journal, Vol. 58, pp. 739-762. E-ISSN 1948-0989, ISSN 0001-4273. DOI 10.5465/amj.2013.0991.

[31] Sajtos, L. and Mitev, A. (2007) "SPSS Kutatási és adatelemzési kézikönyv", Alinea Kiadó, ISBN 978-963-9659-08-7. (in Hungarian).

[32] Soule, D. L., Puram, A. D., Westerman, G. F. and Bonnet, D. (2016) "Becoming a Digital Organization: The Journey to Digital Dexterity", SSRN Electronic Journal, $25 \mathrm{p}$. E-ISSN 1556-5068. DOI 10.2139/ssrn.2697688.

[33] Várallyai, L., Herdon, M. and Botos, S. (2015) "Statistical Analyses of Digital Divide Factors", Procedia Economics and Finance, Vol. 19, pp. 364-372. ISSN 2212-5671. DOI 10.1016/S2212-5671(15)00037-4. 
[34] Vieru, D. (2015) "Towards a multi-dimensional model of digital competence in smalland mediumsized enterprises", in Khosrow-Pour, M. (Ed.) "Encyclopedia of Information Science and Technology", $3^{\text {rd }}$ ed., IGI Global, Hershey PA, pp. 6715-6725. ISBN-13: 978-1466658882. ISBN-10: 1466658886.

[35] Wang, S. K., Hsu, H. Y., Reeves, T. C. and Coster, D. C. (2014) "Professional development to enhance teachers' practices in using information and communication technologies (ICTs) as cognitive tools: lessons learned from a design-based research study", Computers \& Education, Vol. 79, pp.101-115. ISSN 0360-1315. DOI 10.1016/j.compedu.2014.07.006.

[36] Wang, Y. and Haggerty, N. (2011) "Individual virtual competence and its influence on work outcomes", Journal of Management Information Systems, Vol. 27, No. 4, pp. 299-334. E-ISSN 1557-928X, ISSN 0742-1222. DOI 10.2753/MIS0742-1222270410.

[37] Williams, R., de Rassenfosse, G., Jensen, P. and Marginson, S. (2013) "The determinants of quality national higher education systems", Journal of Higher Education Policy and Management, Vol. 35, No. 6, pp. 599-611. E- ISSN 1469-9508, ISSN 1360-080X. DOI 10.1080/1360080x.2013.854288. 